\title{
CAN THE INVASIVE NEW ZEALAND MUD SNAIL (POTAMOPYRGUS ANTIPODARUM) THREATEN FISHERIES OF TEMPERATE LAKES? A CASE STUDY FROM LAKE DUSIA, LITHUANIA
}

\author{
Vytautas RAKAUSKAS ${ }^{1 *}$, Egle ŠIDAGYTE் ${ }^{1}$, Vytautas KESMINAS ${ }^{1}$, \\ and Osvaldas KAMINSKAS ${ }^{1}$ \\ ${ }^{1}$ Nature Research Centre, Vilnius, Lithuania
}

\begin{abstract}
Rakauskas V., Šidagytė E., Kesminas V., Kaminskas O. 2018. Can the invasive New Zealand mud snail (Potamopyrgus antipodarum) threaten fisheries of temperate lakes? A case study from Lake Dusia, Lithuania. Acta Ichthyol. Piscat. 48 (1): 37-49.
\end{abstract}

\begin{abstract}
Background. To date, numerous studies of the impact of snail Potamopyrgus antipodarum (Gray, 1843) on invaded ecosystems have been conducted. However, the majority of such studies intended to assess changes induced in macroinvertebrate assemblages, while the possible effects of $P$. antipodarum on higher trophic levels have not hitherto been studied. Of particular interest from the point of view of fisheries management is the elucidation of how this invasive snail can alter the energy flow towards higher trophic levels. When abundant, $P$. antipodarum consumes a substantial part of the primary production, but it is poorly consumed by native fishes. Consequently, part of its assimilated energy may become locked in lower trophic levels and fail to reach higher levels directly. Therefore, invasion of this snail may decrease fish production.

Materials and methods. Several years after establishment of $P$. antipodarum in a temperate mesotrophic Lake Dusia, we assessed: (1) changes in the biomass of littoral macroinvertebrates (proxy to secondary production), (2) assimilation of $P$. antipodarum by benthivorous fish (energy flow), and (3) changes in growth and catches of littoral benthivorous fish (fish production). All the analyses were based on a merger of "grey" literature and original data during the pre- and post-invasion periods.

Results. There was an evident increase in the biomass of littoral macroinvertebrates, and the assemblage changed from crustacean- to gastropod-dominated due to over-domination of P. antipodarum. However, P. antipodarum did not replace the native prey of fish. Moreover, a marked decrease was recorded in littoral fish growth and catches after the invasion of $P$. antipodarum.

Conclusion. Dense populations of $P$. antipodarum may reduce the channelling of primary production towards higher trophic levels and, consequently, the invasion may threaten fisheries of temperate mesotrophic lakes.
\end{abstract}

Keywords: Aquatic invasion, secondary production, fish diet, fish production, food webs.

\section{INTRODUCTION}

The New Zealand mud snail, Potamopyrgus antipodarum (Gray, 1843) (Mollusca: Tateidae) is one of the most widespread invasive species in the world. The snail is native to New Zealand and its adjacent islands (Winterbourn 1970) and exhibits all properties of an invasive species (Alonso and Castro-Díez 2008). Firstly, it is established in a wide variety of freshwater and estuarine habitats on all the continents except for Africa and Antarctica (Ponder 1988, Grigorovich et al. 2003, Collado 2014). Secondly, in invaded ranges, P. antipodarum reproduces parthenogenetically (Dybdahl and Drown 2011, Hamada et al. 2013). Thirdly, due to its hard shell, small size, and low nutritional value the species is avoided by the majority of native predators (Bersine et al. 2008, Brenneis et al. 2011, Rakauskas et al. 2013, 2016). Furthermore, if preyed upon by fish, some individuals of
P. antipodarum are able to survive the digesting process and fully recover after evacuation (Vinson and Baker 2008, Brenneis et al. 2011, Rakauskas et al. 2016). Up until now, only the tidewater goby, Eucyclogobius newberryi (Girard, 1856), were documented to prey upon and fully digest it under natural conditions (Hellmair et al. 2011). Overall, $P$. antipodarum usually reaches enormously high densities in invaded range (up to 800000 ind. per $\mathrm{m}^{-2}$ ) causing drastic changes both at community and ecosystem levels (Hall et al. 2003, Kerans et al. 2005, Bennet et al. 2015).

Although present in Europe for more than 100 years (Nikolaev 1951), P. antipodarum is still undergoing its expansion further into the temperate freshwater ecosystems of the continent (Filippenko and Son 2008, Radea et al. 2008, Son 2008). For many years after its first record in Lithuania in 1954 (Gasûnas 1959), it was restricted

* Correspondence: Dr Vytautas Rakauskas, Hidrobiontų ekologijos ir fiziologijos laboratorija, Gamtos tyrimų centras, Akademijos g. 2, LT-08412 Vilnius, Lithuania, phone: +37 061-290-735, e-mail: (VR)vytucio@gmail.com, (EŠ) e.sidagyte@gmail.com, (VK) v.kesminas1@gmail.com, (OK) osvaldas.kaminskas@valkam.net. 
only to the brackish waters of the Curonian Lagoon and the Baltic Sea coast (Šivickis 1960, Zettler and Daunys 2007). However, a rapid invasion into Lithuanian inland lakes and rivers has been observed since 2010 (Butkus et al. 2012, 2014).

Due to the high density of $P$. antipodarum during the initial invasion phase of population explosion, the most severe impact is suffered by recently invaded ecosystems (Hall et al. 2003, Kerans et al. 2005, Moore et al. 2012). Thus, studies of such ecosystems may reveal not only effects on invaded macroinvertebrate assemblages but also impacts on fish stocks. To date, numerous studies of the impact of $P$. antipodarum on invaded ecosystems have been conducted (e.g., Kerans et al. 2010, Moore et al. 2012, Bennett et al. 2015). However, the majority of such studies intended to assess changes induced in macroinvertebrate assemblages (e.g., Riley et al. 2008, Kerans et al. 2010, Rakauskas et al. 2018). If broader-scale impacts were studied, these studies were performed mostly in estuarine or riverine ecosystems (e.g., Brenneis et al. 2011, Moore et al. 2012, Bennett et al. 2015). Meanwhile, effects of $P$. antipodarum on higher trophic levels, especially in lakes, have not been studied so far. Understanding the propagation of $P$. antipodarum invasion impacts on higher trophic levels could help to predict the effects on ecosystems more accurately and develop more effective strategies for fisheries management and environmental protection.

This paper addresses the potential impacts of $P$. antipodarum on the fisheries in a temperate mesotrophic lake. A conjunction of the facts that (1) P. antipodarum may become abundant, (2) it consumes a substantial portion of lake primary production, and (3) it is not proportionally targeted by native predators, raises a legitimate concern that it may reduce the direct energy flow to higher trophic levels, leaving part of the primary production blocked from ascending further up the trophic chain (Rakauskas et al. 2016, 2018).

In the presently reported study, the recently invaded temperate mesotrophic lake, Dusia, Lithuania, became a model system for studying the impact of $P$. antipodarum on the natural environment. This is primarily due to a very rapid, strong, and rather well documented invasion of this snail (Butkus et al. 2012, 2014, Rakauskas et al. 2018). Secondly, the lake has been monitored by our research team for quite some time before the invasion, which allowed us to obtain the baseline macroinvertebrate and fish data. Lastly, frequent monitoring of water trophic parameters* and commercial fish catches ${ }^{* *}$ in this lake of high national importance allowed us to control for changes in important factors that could interfere with the outcomes of our study. While mesocosm experiments allow for bettercontrolled hypothesis testing, they are frequently disputed as unrealistic simplifications with limited relevance to natural ecosystems, especially when assessing broaderscale impacts (Carpenter 1996, Schindler 1998, Haag and Matschonat 2001).
To assess how $P$. antipodarum affects lake's secondary production we compared the biomass of littoral macroinvertebrates between the pre- and post-invasion periods. Seasonal diet analysis of benthivorous fish was performed to evaluate $P$. antipodarum integration into higher trophic levels. To determine its current effects on higher trophic levels, we also compared relevant fish community aspects between the pre- and post-invasion periods.

\section{MATERIALS AND METHODS}

Study site. Lake Dusia $\left(54^{\circ} 17^{\prime} \mathrm{N} 23^{\circ} 41^{\prime} \mathrm{E}\right.$, South Lithuania, Baltic Sea drainage) is a post-glacial freshwater lake. It is a relatively large $\left(23.3 \mathrm{~km}^{2}\right)$, medium deep (mean and max. depths: 15.4 and $32.4 \mathrm{~m}$, respectively) lake with annual water turnover of only 6\% (Kilkus 1998). The lake has a wide sandy littoral, stretching 100-350 m offshore and covering $12 \%$ of the lake area. The hypolimnion starts at a depth of 12-16 m (Kilkus 1998). According to the prevailing indicator fish species, Lake Dusia should be considered a smelt lake (Virbickas 1988, Virbickas et al. 1996). The fish community is primarily composed of cold-water fish characteristic of ecosystems at early succession stages, i.e., Osmerus eperlanus (Linnaeus, 1758) and Coregonus albula (Linnaeus, 1758). In addition to these dominant species, the lake is inhabited by fishes of other ecological groups, i.e., Perca fluviatilis Linnaeus, 1758, Gymnocephalus cernua (Linnaeus, 1758), and Rutilus rutilus (Linnaeus, 1758) (see Virbickas 2013, Pilinkovskij et al. 2014).

The littoral macroinvertebrate assemblage of Lake Dusia had been enriched in the past with several PontoCaspian species. The zebra mussel Dreissena polymorpha (Pallas, 1771) is a historical invader with published records in the lake predating 1940s (Schlesch and Krausp 1938, Arbačiauskas et al. 2011). Later in the 1960s, amphipods: Chaetogammarus warpachowskyi Sars, 1897, Obesogammarus crassus (Sars, 1894), Pontogammarus robustoides (Sars, 1894) and mysid Paramysis lacustris (Czerniavsky, 1882) were introduced (Arbačiauskas et al. 2011). Due to particularly suitable conditions in this lake, it only took three years for these crustaceans to fully establish (Gasûnas 1970, 1975, Arbačiauskas 2005). Since then, these populations of Ponto-Caspian species are known to remain stable (Gasûnas 1975, Arbaciauskas 2002, Gumuliauskaitė unpublished ${ }^{* * *}$ ), serving as valuable prey for native fish (Gasûnas 1972, Arbačiauskas et al. 2010, Rakauskas et al. 2010). Several decades from these swift introductions until the invasion of $P$. antipodarum must have been sufficient for the ecosystem to reach an equilibrium state. Therefore, it is highly unlikely that these fully integrated Ponto-Caspian species could somehow interfere with the current study, and thus within this paper, they are treated as native.

During repeated macroinvertebrate surveys within 2003-2006 P. antipodarum was not detected in Lake Dusia (Gumuliauskaite unpublished ${ }^{* * *}$ ), but when the

\footnotetext{
* Data on water trophic parameters in Lake Dusia during 2001-2016 kindly provided by the Ministry of Environment of the Republic of Lithuania.

** Data on commercial catches in Lake Dusia during 2001-2015 kindly provided by the Ministry of Environment of the Republic of Lithuania.

*** Gumuliauskaitė S. 2007. Ponto-Kaspijos šoniplaukos Pontogammarus robustoides gyvenimo ciklas ir poveikiai Lietuvos gẻlų vandenų bendrijoms. [Life cycle and impacts of Ponto-Caspian amphipods on the Lithuanian freshwater ecosystems]. Ph.D. thesis, Vilnius University, Vilnius, Lithuania. [In Lithuanian.]
} 
surveys were renewed in 2010, the snail was already found to constitute over $30 \%$ of macroinvertebrate abundance and biomass (Butkus et al. 2012, Rakauskas et al. 2016, 2018). These findings indicated that $P$. antipodarum invaded the lake between 2007 and 2009, thus this period was excluded from our study. For the last three years (2014-2016), P. antipodarum remained a super-dominant macroinvertebrate species, with both abundance and biomass exceeding $70 \%$ and still showing a slight increase (Rakauskas et al. 2018).

Macroinvertebrate data. The pre-invasion macroinvertebrate assemblage could be well represented by data available from repeated surveys performed during 2003-2006 (Gumuliauskaitė unpublished*). We collected the post-invasion macroinvertebrate samples in 2014-2016 and supplemented them with available data from 2010 (Šidagyte, unpublished data), when $P$. antipodarum was also already established (Butkus et al. 2012). The macroinvertebrate data from 2011-2013 were not available.

For the pre- and post-invasion periods, the same lake site with sandy bottom and some macrophytes (Potamogeton sp., Phragmites australis) was sampled once per year, between late August and September. On each sampling occasion, three random replicates of quantitative macroinvertebrate samples were collected at a depth of 0.5-1.0 m using a custom-made "stovepipe" sampler with a cross-section area of $0.1 \mathrm{~m}^{2}$. Preserved in $70 \%$ ethanol in the field, in the laboratory the samples were examined for macroinvertebrates that were sorted by family, and then counted and weighed (wet weight) to the nearest $0.1 \mathrm{mg}$ (electronic balance, ABJ 120-4M, Kern and Sohn GmbH). Seasonal diet of benthivorous fish. The diet was analysed using fish caught in spring, summer, and autumn of 2015 and 2016 (post-invasion period). Each season we analysed up to 70 fish individuals representing each of five fish species: Perca fluviatilis, Rutilus rutilus, Gymnocephalus cernua, Tinca tinca (Linnaeus, 1758), and Abramis brama (Linnaeus, 1758). In total, gut contents of 309 specimens were examined (fish with empty stomachs were excluded). As $P$. fluviatilis undergoes ontogenetic diet shifts (Hjelm et al. 2000, Horppila et al. 2000, Svanbäck and Eklöv 2002), the specimens were subdivided into two length groups: small $(11-15 \mathrm{~cm})$ and medium $(17-21 \mathrm{~cm})$.

After euthanizing the fish by immersing them into 1.5-2.0 $\mathrm{mL} \cdot \mathrm{L}^{-1}$ solution of 2-phenoxyethanol for $5 \mathrm{~min}$ ), their digestive tracts were immediately removed and preserved in $10 \%$ formaldehyde solution until the necropsy in the laboratory. Gut contents (found in the stomachs or the predetermined fore-/mid-gut sections of the stomach-less fish) were dissected out, and food items were identified, grouped, and weighed (wet-weight) to the nearest $0.1 \mathrm{mg}$ (electronic balance, ABJ 120-4M, Kern and Sohn GmbH). Digested and thus unidentifiable particles were classified as 'miscellaneous stomach content', and their weight was proportionally distributed among identified food items.

Growth and standardised catches of littoral fish. Littoral fish were sampled from early July to late
September during the pre- (2001-2006) and post-invasion (2010, 2012-2015) periods. No fish data were available from 2011. At a depth of 2.0-5.0 m, fish were caught using multi-mesh benthic gillnets (30 to $60 \mathrm{~m}$ in length and $3 \mathrm{~m}$ in height). The mesh size varied and was $14,18,22,25$, $30,40,50,60$, and $70 \mathrm{~mm}$. On each sampling occasion, net sets of length from 320 to $1840 \mathrm{~m}$ were used. Nets were positioned randomly to cover different parts and depths of the littoral zone, and left for at least $12 \mathrm{~h}$ overnight including the sunset and the sunrise.

In total, 9409 fish specimens were identified, measured to the nearest $1 \mathrm{~mm}$, weighed to the nearest $0.1 \mathrm{~g}$, and their age was determined from scales (Thoresson 1993) for growth assessment. As catches of other fish species were extremely sporadic (see Results), the growth of only P. fluviatilis (small - up to age $6+, 369$ specimens in total) and $R$. rutilus (339 specimens) was assessed. Catch per unit effort (CPUE) of all fishes was estimated as biomass or a number of individuals (abundance) caught using a standard 30-m long gillnet in one night. If there were multiple sampling occasions per year, the estimates were based on the mean value.

Trophic state and commercial fishing data. Changes in productivity or commercial fishing may substantially affect standardised fish catches and growth (Virbickas and Stakenas 2016), masking the effects of invasions. Thus, to legitimise the intended analysis of $P$. antipodarum invasion effects on fisheries of Lake Dusia, we also assessed changes in trophic state and commercial catches of littoral fish. To assess the trend in the trophic state, annual mean values of physicochemical parameters, such as Secchi depth, total $\mathrm{N}$, total $\mathrm{P}$, and chlorophyll $a$ concentrations, were obtained for the period of 2001-2016*. The data for comparing the commercial fish catches were obtained for the pre- (2001-2006) and post-invasion (2010-2015) periods $^{* *}$. No commercial fishing occurred in 2016, as it was forbidden in all state inland waters since that year (Anonymous 2016).

Statistical analyses. To assess the impact of $P$. antipodarum invasion on total, native (excluding P. antipodarum) and relative macroinvertebrate biomasses, nested ANOVAs were fitted with the year factor nested within the invasion period factor (pre- vs. post-). These were followed by Fisher LSD post-hoc tests in cases of total and native biomasses to identify significant pairwise differences between years.

To test the $P$. antipodarum invasion effect (pre- vs. post-) on the growth of $R$. rutilus and P. fluviatilis, homogeneity of slopes (HOS) models were fitted to individual fish weights using fish age as a covariate. To assess the invasion impact on fish CPUEs (total catches and those of separate species) in terms of abundance and biomass, $t$-tests (pre- vs. post-) were used.

Temporal trends in lake trophic state were evaluated using Pearson's correlations between each available physico-chemical parameter and the year variable.

\footnotetext{
" See the respective footnote on page 38 .

** See the respective footnote on page 38.
} 
Commercial fish catches before and after the invasion were compared using a $t$-test.

For the analyses, commercial fish catches, macroinvertebrate biomasses (total, excluding $P$. antipodarum, and relative), individual weights of R. rutilus and P. fluviatilis, as well as CPUEs of separate fish in terms of abundance and biomass were logtransformed. Such transformation ensured that model assumptions of data homoscedasticity and normality were met in all analyses. The homoscedasticity assumption was tested using Bartlett tests $(P>0.093)$ and the normality of model residuals was tested using Shapiro-Wilk tests $(P>0.077)$. The analyses were performed using STATISTICA 12.0 software. The significance level of $P<0.05$ was specified for all statistical analyses a priori.

\section{RESULTS}

A shift in macroinvertebrate assemblage. Since its initial detection in 2010, the biomass of P. antipodarum in the littoral zone of Lake Dusia has been constantly increasing
(Fig. 1). Although total biomass of macroinvertebrates varied substantially between years (nested ANOVA, year effect: $F_{6,16}=10.1, P<0.001$; Fig. 1A), it was generally significantly larger during the post-invasion period (invasion effect: $F_{1,16}=8.7, P=0.010$; Fig. 1B). The between-year variation was also significant in case of native (excluding $P$. antipodarum) macroinvertebrate biomass (nested ANOVA, year effect: $F_{6,16}=6.9, P<$ 0.001 ; Fig. 1C). However, there was a significant decrease in it after the invasion (invasion effect: $F_{1,16}=6.3, P=$ 0.024; Fig. 1D).

Overall, the littoral macroinvertebrate community of Lake Dusia changed from being dominated by crustaceans to one dominated by gastropod mollucs, predominantly P. antipodarum (Fig. 2). After the invasion, the relative crustacean biomass significantly decreased from $46.8 \pm$ 29.8 to $11.3 \pm 12.1 \%$ (nested ANOVA, invasion effect: $F_{1}$. $\left.{ }_{16}=23.2, P<0.001\right)$. Conversely, the relative biomass of gastropods increased from $24.5 \pm 25.7$ to $75.7 \pm 20.6 \%$ (nested ANOVA, invasion effect: $F_{1,16}=28.9, P<0.001$ ).
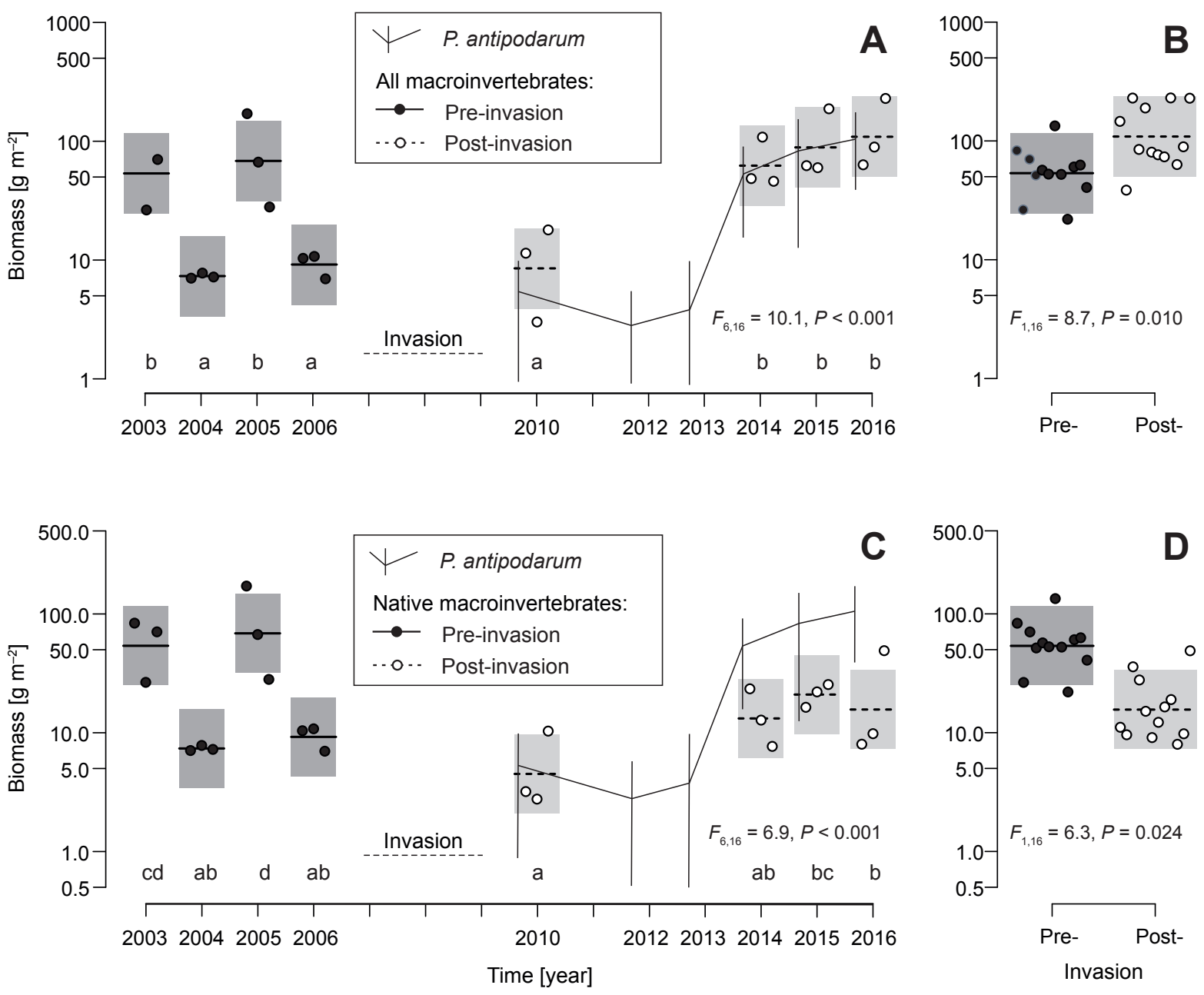

Fig. 1. Effects of between-year variation and Potamopyrgus antipodarum invasion on total (A, B) and native (excl. P. antipodarum; C, D) biomasses of littoral macroinvertebrates in Lake Dusia: predictions (with $95 \%$ confidence bands and partial residuals) made from nested ANOVAs; periods: before (Pre-) and after (Post-) the invasion; biomass (mean $\pm \mathrm{SD}$ ) of $P$. antipodarum in the Lake Dusia littoral denoted by solid line; note the logarithmic scale of vertical axes; small letters (a, b, c, d) denote homogeneous year groups according to Fisher LSD tests 
Seasonal fish diet. The analysis of fish diet during the post-invasion period (Fig. 3) showed that molluscs were the dominant prey item only in the diet of cyprinids (T. tinca, A. brama, and R. rutilus). The share of molluses in the diet of these fish species varied from $40 \%$ to $95 \%$ with the exception of the spring and autumn diets of A. brama, which were dominated by insects. The share of molluscs in the diet of percids (P. fluviatilis and G. cernua) was generally negligible, but it was considerable $(22 \%)$ within the autumn diet of G. cernua. However, bivalves (Dreissena polymorpha, Pisidium sp. and Sphaerium sp.) and native gastropods (Bithynia sp.) were the dominant molluscan prey, while the share of $P$. antipodarum in the diet of the studied fish species did not exceed $6 \%$ throughout all the seasons (Table 1).

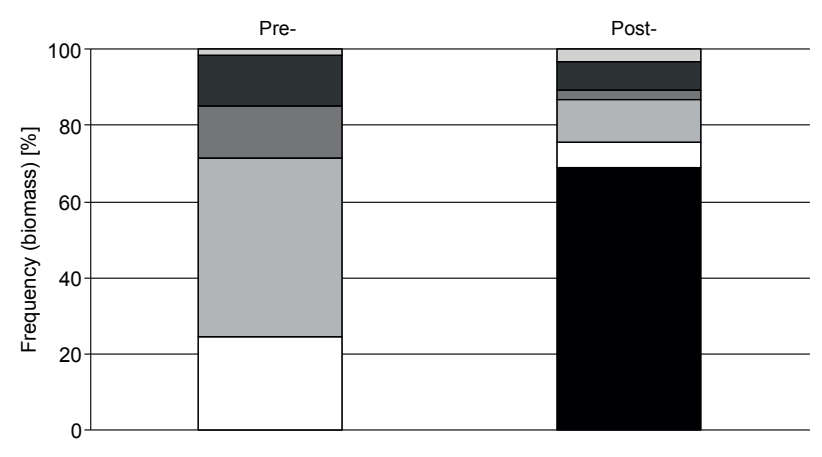

- P. antipodarum $\square$ Gastropoda $\square$ Crustacea $\square$ Diptera $\square$ Bivalvia $\square$ Other

Fig. 2. Mean relative biomasses of littoral macroinvertebrate groups in Lake Dusia before (Pre-; 2003-2006) and after (Post-; 2010, 2014-2016) invasion of Potamopyrgus antipodarum

Changes in fish growth and CPUE. The comparison of $P$. Aluviatilis and $R$. rutilus growth revealed marked differences between the pre- and post-invasion periods (Table 2). After $P$. antipodarum invasion, the growth of $R$. rutilus significantly decreased (HOS model, age $\times$ invasion effect: $F_{1,335}=9.6, P=0.002$; Fig. 4 A). The interaction term in the $P$. fluviatilis model was insignificant (HOS model, age $\times$ invasion effect: $F_{1,365}=0.4, P=0.5$ ), but there was an overall significant decrease in size of small benthivorous $P$. fluviatilis during the post-invasion period (invasion effect: $F_{1,365}=10.3, P=0.001$; Fig. 4B).

After the invasion of $P$. antipodarum, CPUEs of littoral fishes, in terms of total biomass and abundance, significantly decreased ( $t$-tests: $t_{9}=2.5, P=0.031$ and $t_{9}=3.1, P=0.012$, respectively; Fig. 5). However, when data for separate species (Table 3), such as A. brama, P. fluviatilis, R. rutilus, and T. tinca, were compared, no significant differences were revealed either in terms of biomass or abundance ( $t$-tests: $P>0.46$ and $P>0.38$, respectively). Only CPUEs of $G$. cernua significantly decreased after the invasion ( $t$-tests: for biomass, $t_{9}=7.2$, $P<0.001$; for abundance, $\left.t_{9}=4.6, P=0.001\right)$.

Trophic state and commercial fish catches. According to physicochemical parameters, Lake Dusia could be classified as mesotrophic with tendencies towards a eutrophic state. The ranges of the annual mean values of Secchi depth, total N, total $\mathrm{P}$, and chlorophyll $a$ concentrations were as follows: $2.9-7.0 \mathrm{~m}, 450-1146 \mu \mathrm{g}$ $\cdot \mathrm{L}^{-1}, 20-54 \mu \mathrm{g} \cdot \mathrm{L}^{-1}$, and $2.63-10.34 \mu \mathrm{g} \cdot \mathrm{L}^{-1}$, respectively. No significant temporal trends in any of these parameters could be identified (Pearson's correlations: $r<0.5$, $P>0.21)$. The pre- and post-invasion periods did not

Table 1

Seasonal prevalence of snail, Potamopyrgus antipodarum, in the diet of fish in Lake Dusia, Lithuania, within 2015-2016

\begin{tabular}{lcccccc}
\hline \multicolumn{1}{c}{ Fish species } & Season & $n$ & TL [cm] & PR [\%] & $I$ [ind.] & $S[\%]$ \\
\hline Abramis brama & SPR & 2 & $53.2 \pm 13.4$ & 50.0 & $9.0 \pm 0$ & 1.0 \\
Gymnocephalus cernua & SPR & 42 & $13.5 \pm 2.9$ & 23.8 & $4.1 \pm 8.8$ & 4.2 \\
Perca fluviatilis M & SPR & 17 & $18.3 \pm 1.6$ & 52.9 & $2.2 \pm 2.0$ & 3.4 \\
Perca fluviatilis S & SPR & 12 & $14.8 \pm 0.6$ & 41.7 & $1.0 \pm 0$ & 3.0 \\
Rutilus rutilus & SPR & 8 & $22.5 \pm 6.4$ & 25.0 & $2.0 \pm 1.4$ & 1.6 \\
Abramis brama & SUM & 4 & $31.4 \pm 6.3$ & 50.0 & $15.5 \pm 17.7$ & 4.8 \\
Gymnocephalus cernua & SUM & 10 & $10.9 \pm 1.9$ & 10.0 & $3.0 \pm 0$ & 1.1 \\
Perca fluviatilis M & SUM & 4 & $17.3 \pm 0.5$ & 25.0 & $6.0 \pm 0$ & 2.5 \\
Perca fluviatilis S & SUM & 10 & $12.1 \pm 1.9$ & 30.0 & $1.3 \pm 0.6$ & 2.9 \\
Rutilus rutilus & SUM & 34 & $19.7 \pm 3.6$ & 32.4 & $13.8 \pm 14.6$ & 6.0 \\
Tinca tinca & SUM & 1 & 34.5 & 0 & 0 & 0 \\
Abramis brama & AUT & 12 & $34.7 \pm 3.5$ & 41.7 & $3.6 \pm 2.4$ & 0.2 \\
Gymnocephalus cernua & AUT & 43 & $12.3 \pm 1.7$ & 20.9 & $2.6 \pm 2.4$ & 3.9 \\
Perca fluviatilis M & AUT & 10 & $17.9 \pm 2.1$ & 0 & 0 & 0 \\
Perca fluviatilis S & AUT & 24 & $12.8 \pm 1.8$ & 4.2 & $7.0 \pm 0$ & 0.05 \\
Rutilus rutilus & AUT & 70 & $21.1 \pm 5.4$ & 28.6 & $10.6 \pm 18.3$ & 4.4 \\
Tinca tinca & AUT & 6 & $26.8 \pm 6.8$ & 60.0 & 0 & 0.3 \\
\hline
\end{tabular}

$n=$ number of fish specimens analysed, $\mathrm{TL}=$ total body length of fish (mean \pm standard deviation), $\mathrm{PR}=$ percentage of fish specimens that ingested $P$. antipodarum, $I=$ number of ingested $P$. antipodarum individuals per fish specimen (mean \pm standard deviation), $S=$ relative biomass (share) of $P$. antipodarum in fish diet; $\mathrm{SPR}=$ spring, $\mathrm{SUM}=$ summer, $\mathrm{AUT}=$ autumn; $\mathrm{S}=$ small, $\mathrm{M}=$ medium. 
differ in commercially caught littoral fish biomass either ( $t$-test: $t_{9}=1.2, P=0.273$ ).

\section{DISCUSSION}

Impacts of invasive mollusc species on invaded ecosystems are usually major and cause significant shifts in diversity, abundance, and biomass of indigenous fauna (Nalepa 1994, Karatayev et al. 1997, Sampaio and Rodil 2014). Previous studies showed that $P$. antipodarum

Table 2

Results of homogeneity of slopes models testing for impact of fish age and Potamopyrgus antipodarum invasion on body weight of Rutilus rutilus and Perca fluviatilis in Lake Dusia, Lithuania (see Fig. 4 for prediction plots)

\begin{tabular}{llcccc}
\hline Fish species & \multicolumn{1}{c}{ Effect } & df & MS & $F$ & $P$ \\
\hline R. rutilus & Age & 1 & 194.38 & 3280.5 & $<0.001$ \\
& Invasion & 1 & 0.07 & 1.2 & 0.282 \\
& Age $\times$ Invasion & 1 & 0.57 & 9.6 & 0.002 \\
& Error & 335 & 0.06 & & \\
P. fluviatilis & Age & 1 & 124.97 & 3232.9 & $<0.001$ \\
& Invasion & 1 & 0.40 & 10.3 & 0.001 \\
& Age $\times$ Invasion & 1 & 0.01 & 0.4 & 0.539 \\
& Error & 365 & 0.04 & & \\
\hline
\end{tabular}

$\mathrm{df}=$ degrees of freedom, $\mathrm{MS}=$ mean squares, $F=F$-statistic, $P=$ probability; significant probabilities $(P<0.05)$ are set in bold type. frequently reaches enormously high densities in invaded ecosystems, causing changes in nitrogen and carbon cycling (Hall et al. 2003, Arango et al. 2009), consumption of primary production (Riley et al. 2008), and macroinvertebrate assemblages (Kerans et al. 2005, Moore et al. 2012). Furthermore, it has been shown that $P$. antipodarum may replace valuable food sources in the diet of benthivorous fish, and even reduce survivorship of fish that consume it (Vinson and Baker 2008). This study revealed changes in the ecosystem of Lake Dusia at several trophic levels, which coincided with the invasion of $P$. antipodarum. Firstly, the biomass and composition of littoral macroinvertebrate assemblage have changed. Moreover, a decrease in standardised littoral fish catches and growth rate of some benthivorous fish species was observed. These changes may be attributed to the negative $P$. antipodarum effects on the littoral macroinvertebrate community as trophic state and commercial fish catches did not change during the study, and there is no reason to believe that intensity of recreational fishing has changed. We suggest that $P$. antipodarum may decrease fish production by (1) over-domination and shifting the macroinvertebrate assemblage structure towards less favourable for fish feeding, (2) decreasing the biomass of native macroinvertebrates through competition, or (3) reducing the channelling of the energy stored in secondary production towards higher trophic levels due to its ability to avoid predation by benthivorous predators.

Changes in lake secondary production. Our study revealed a significant increase in the total macroinvertebrate
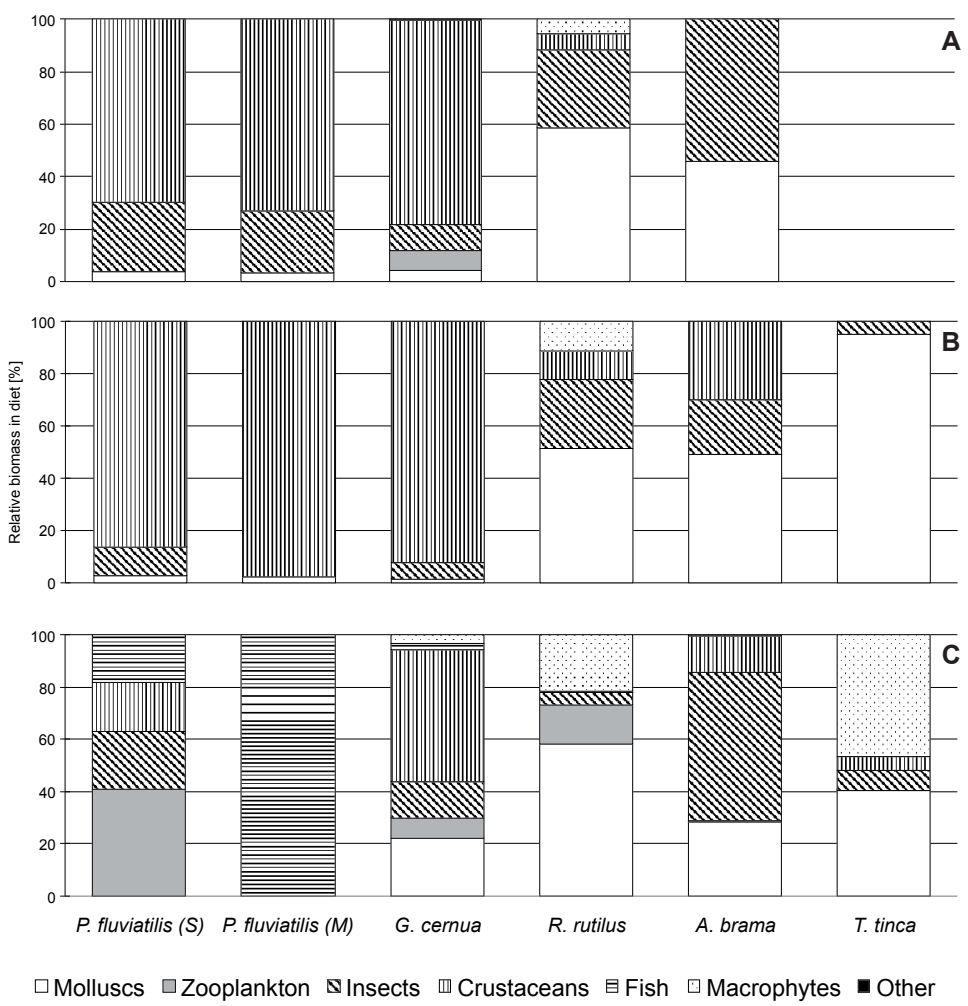

Fig. 3. Seasonal diet composition of fish in Lake Dusia during 2015-2016: spring (A), summer (B), and autumn (C); analysed fish: Perca fluviatilis, Gymnocephalus cernua, Rutilus rutilus, Abramis brama, Tinca tinca; size categories of Perca fluviatilis: $\mathrm{S}=$ small, $\mathrm{M}$ = medium; see Table 1 for fish numbers and sizes, and details on Potamopyrgus antipodarum within shown diets 
biomass after the $P$. antipodarum invasion in Lake Dusia. Therefore, the conjecture that the $P$. antipodarum appearance supplements the littoral macroinvertebrate community and its total biomass increases due to the enhanced utilisation of primary production and detritus was confirmed. On the other hand, the total biomass of native macroinvertebrates was shown to significantly decrease indicating high $P$. antipodarum competition with native invertebrates. This result is in accord with previous studies which showed that $P$. antipodarum competition can be detrimental to native invertebrates (Múrria et al. 2008, Riley et al. 2008, Kerans et al. 2010). Overall, such a decline in native macroinvertebrates may imply that
P. antipodarum exerts negative impacts on the dominant forage base of benthivorous fish in the littoral zone of Lake Dusia.

Nevertheless, our analysis showed evident changes in the biomass proportions of some macroinvertebrate groups. The drastic increase in gastropods and the decrease in crustaceans were observed after $P$. antipodarum invasion. The relative biomass of gastropods grew up to $75 \%$, while the relative biomass of crustaceans shrank and constituted less than 12\%. Previous studies have also shown that $P$. antipodarum can both positively and negatively relate to densities of native macroinvertebrates
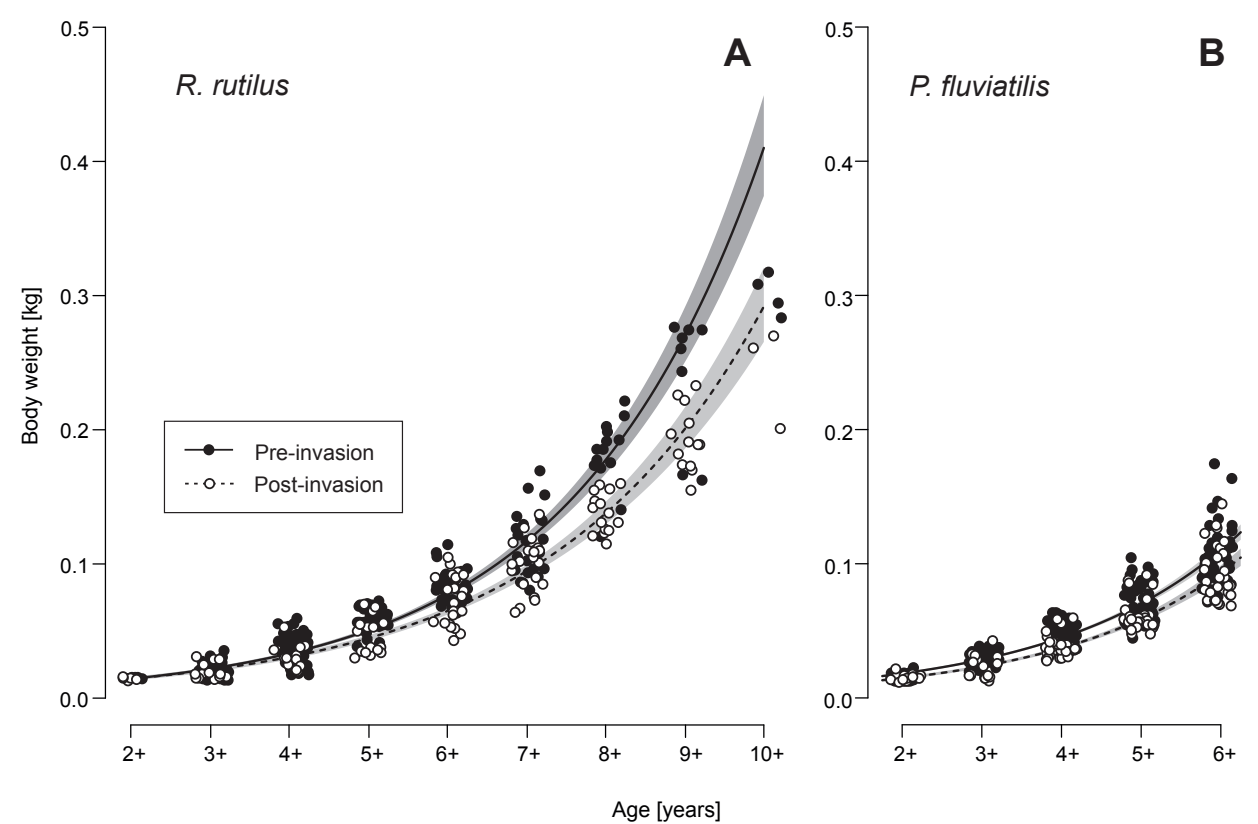

Fig. 4. Growth of Rutilus rutilus (A) and Perca fluviatilis (B) in Lake Dusia before (Pre-) and after (Post-) the invasion of Potamopyrgus antipodarum: predictions (with 95\% confidence bands and partial residuals) of the homogeneity of slopes models (see Table 2 for effect tests)

Table 3

Standardised catches (catch per unit effort) of littoral fishes in Lake Dusia, Lithuania, before (2001-2006) and after

(2010-2015) invasion of Potamopyrgus antipodarum

\begin{tabular}{|c|c|c|c|c|c|c|c|c|c|c|c|c|c|c|}
\hline \multirow{2}{*}{ Year } & \multicolumn{2}{|c|}{ A. brama } & \multicolumn{2}{|c|}{ G. cernua } & \multicolumn{2}{|c|}{ P. fluviatilis } & \multicolumn{2}{|c|}{ R. rutilus } & \multicolumn{2}{|c|}{ T. tinca } & \multicolumn{2}{|c|}{ Other } & \multicolumn{2}{|c|}{ Total } \\
\hline & $\mathrm{BM}$ & $\mathrm{AB}$ & $\mathrm{BM}$ & $\mathrm{AB}$ & $\mathrm{BM}$ & $\mathrm{AB}$ & $\mathrm{BM}$ & $\mathrm{AB}$ & $\mathrm{BM}$ & $\mathrm{AB}$ & $\mathrm{BM}$ & $\mathrm{AB}$ & $\mathrm{BM}$ & $\mathrm{AB}$ \\
\hline 2001 & 0.0 & 0.0 & 0.7 & 30.3 & 1.2 & 20.0 & 0.1 & 1.7 & 0.0 & 0.0 & 0.1 & 1.1 & 2.0 & 53.1 \\
\hline 2002 & 0.0 & 0.0 & 0.5 & 16.1 & 0.6 & 11.2 & 0.2 & 2.7 & 0.0 & 0.1 & 0.3 & 1.3 & 1.5 & 31.3 \\
\hline 2003 & 0.0 & 0.3 & 1.0 & 43.6 & 0.6 & 14.2 & 0.5 & 7.9 & 0.2 & 0.3 & 0.2 & 1.8 & 2.5 & 68.1 \\
\hline 2004 & 0.3 & 0.8 & 0.9 & 38.8 & 0.7 & 12.0 & 0.4 & 6.7 & 0.0 & 0.0 & 0.1 & 3.2 & 2.4 & 61.5 \\
\hline 2005 & 0.2 & 0.4 & 0.7 & 22.6 & 1.6 & 19.5 & 0.1 & 1.3 & 0.0 & 0.0 & 0.1 & 0.6 & 2.6 & 44.4 \\
\hline 2006 & 0.0 & 0.0 & 1.0 & 30.7 & 0.7 & 9.9 & 0.1 & 3.3 & 0.0 & 0.0 & 0.1 & 3.8 & 1.9 & 47.8 \\
\hline 2010 & 0.1 & 0.1 & 0.2 & 7.9 & 0.7 & 8.2 & 0.1 & 0.9 & 0.0 & 0.0 & 0.0 & 0.2 & 1.1 & 17.3 \\
\hline 2012 & 0.0 & 0.0 & 0.0 & 1.3 & 1.4 & 36.6 & 0.3 & 5.4 & 0.0 & 0.0 & 0.0 & 0.1 & 1.8 & 43.6 \\
\hline 2013 & 0.1 & 0.0 & 0.2 & 11.8 & 1.3 & 16.6 & 0.1 & 1.4 & 0.1 & 0.3 & 0.2 & 2.9 & 1.9 & 33.1 \\
\hline 2014 & 0.0 & 0.0 & 0.1 & 5.4 & 1.2 & 15.3 & 0.2 & 2.8 & 0.0 & 0.1 & 0.3 & 4.6 & 1.8 & 28.2 \\
\hline 2015 & 0.3 & 0.2 & 0.1 & 6.3 & 0.3 & 3.9 & 0.4 & 4.7 & 0.1 & 0.1 & 0.2 & 0.5 & 1.3 & 15.6 \\
\hline
\end{tabular}

$\mathrm{BM}=$ biomass (kg per year), $\mathrm{AB}=$ abundance (ind. per year); principal fish analysed: Abramis brama, Gymnocephalus cernua, Perca fluviatilis, Rutilus rutilus, Tinca tinca; other species: alburnus alburnus, Anguilla anguilla, Blicca bjoerkna, Carassius gibelio, Esox lucius, Gasterosteus aculeatus, Scardinius erythrophthalmus). 
(Schreiber et al. 2002, Kerans et al. 2005, Rakauskas et al. 2018). A shift towards a macroinvertebrate assemblage dominated by gastropods may have effects on food webs of recipient ecosystems through both direct and indirect interactions. It may affect fisheries as previously dominant crustaceans are an important component in the diet of benthivorous fish species (Bubinas 1979, Kublickas and Bubinas 1985) and provide more energy per unit biomass than tiny, hard-shelled P. antipodarum (see Ryan 1982, McCarter 1986, Sagar and Glova 1995). Consequently, the establishment of a low-quality prey species such as $P$. antipodarum may displace more nutritionally valuable prey items in fish diet and reduce fish growth (Vinson and Baker 2008). Therefore, the rapid spread, population growth, and persistence of $P$. antipodarum in temperate lakes have the potential to affect food webs and fisheries.

Assimilation of secondary production. The increase of secondary production after supplementation by a new invasive primary consumer has a potential for increasing the production of secondary consumers, e.g., benthivorous fish (King et al. 2006, Watzin et al. 2008, Carlsson et al. 2009). However, such augmentation of fisheries could be expected only if channelling of the energy stored in increased secondary production (new primary consumers, e.g., P. antipodarum) toward higher trophic levels (secondary consumers, e.g., benthivorous fishes) is ensured. This requires that the invasive species would serve as high-quality, easily accessible and readily consumed fish-food (Arbačiauskas et al. 2010). If the invasion of $P$. antipodarum in temperate lakes meets this requirement, the growth rate and the standing stock of native benthivorous (and particularly molluscivorous) fish are likely to improve, and an increase in total fish production could be expected.

Benthivorous fish are considered to be the main molluscivores in temperate lake ecosystems (Wetzel
2001). Therefore the integration of secondary production accumulated in the standing stock of $P$. antipodarum towards higher trophic levels is mostly expected through fish predation on this invasive snail. Although the conclusions drawn from our fish diet analysis are limited due to a limited number of analysed fish specimens, some predictions (taking into account previous studies) about their ability to feed on P. antipodarum in Lake Dusia can be made.

This study showed that $P$. antipodarum share in the diet of studied benthivorous fish was very low throughout all seasons, although the contribution of other molluscs to the diet of some fish was significant. Similar results were obtained in previous studies of benthivorous fish performed during autumn in several Lithuanian lakes recently invaded by $P$. antipodarum (Rakauskas et al. 2016), or studies of various fish species in other regions (Bersine et al. 2008, Brenneis et al. 2011). Rakauskas et al. (2016) revealed that in temperate lakes the main benthivorous fishes actually avoid $P$. antipodarum as prey. However, at least in Lithuanian lakes, low integration of $P$. antipodarum into the fish diet may be explained by the fact that this invasive snail has established relatively recently, and native molluscivores may need some time to adapt to the exotic prey. Previous studies demonstrated a steady increase in numbers of $P$. antipodarum ingested by native fish species after its first appearance in the Green River, Utah; however, although a greater number of fishes consumed it, the proportion of this snail in the diet of an individual fish remained the same (Vinson et al. 2006). Thus, the importance of $P$. antipodarum in the diet of benthivorous fish in Lake Dusia may also remain negligible.

Previous studies also demonstrated that the majority of ingested $P$. antipodarum individuals remained intact after passing through the gastrointestinal tract of various fish species both in native and invaded ranges (McCarter
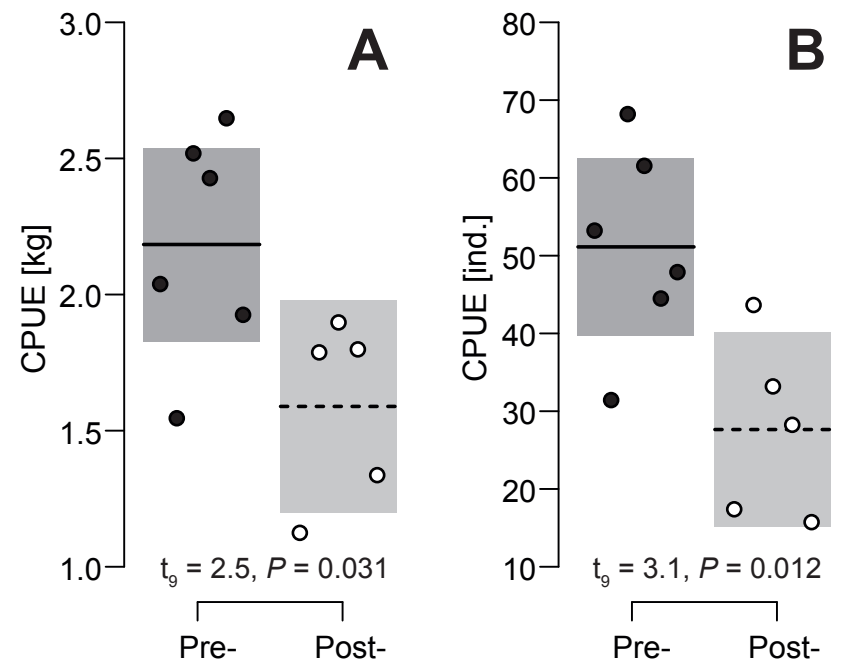

Invasion

Fig. 5. Catch per unit effort (CPUE) of littoral fish in terms of biomass (A) and abundance (B) in Lake Dusia before (Pre-; 2001-2006) and after (Post-; 2010-2015) the invasion of Potamopyrgus antipodarum (means with 95\% confidence bands) 
1986, Jellyman 1989, Rakauskas et al. 2016). Additionally, earlier experiments revealed that $P$. antipodarum is able to survive after passing the guts of various benthivorous fish of temperate lakes (Rakauskas et al. 2016). Overall, compared to other macroinvertebrates $P$. antipodarum has been shown to provide little energy to fish (Ryan 1982, McCarter 1986). This has been confirmed by poor growth of fish fed on $P$. antipodarum (see Vinson and Baker 2008). Therefore, we conclude that $P$. antipodarum is a poor food source for secondary consumers such as fish, because it provides little energy and may pass through the gut undigested. Our study further suggests that the main benthivorous fish avoid consuming $P$. antipodarum in Lake Dusia throughout the season, though it is one of the most abundant macroinvertebrate species in the littoral zone. If native fish do not ingest, digest and assimilate $P$. antipodarum, part of lake primary production may get locked, and the energy flow towards higher trophic levels may be reduced.

Nevertheless, predatory macroinvertebrates may also contribute to the consumption of $P$. antipodarum. Previous studies showed that crayfish, dragonflies, and damselflies consume substantial numbers of $P$. antipodarum under experimental conditions (Brenneis et al. 2011, Bennet et al. 2015, Rakauskas et al. 2016). As these macroinvertebrates are valuable prey for benthivorous fish species they can link the secondary production of $P$. antipodarum with higher trophic levels. However, dragonflies and damselflies were very rare invertebrates in Lake Dusia, and crayfish density was below detection threshold throughout the study period (Rakauskas et al. 2018). Thus, in case of this lake, predatory macroinvertebrates are unlikely to transfer a considerable part of the energy accumulated in the standing stock of $P$. antipodarum towards higher trophic levels. However, the hypothesis warrants further investigation of field diet of other predatory macroinvertebrates, such as leeches, alderflies, or backswimmers in lakes invaded by P. antipodarum.

Fish production. Reduced growth of $R$. rutilus and $P$. fluviatilis in Lake Dusia in the post-invasion period, as demonstrated in our study, may be explained by $P$. antipodarum invasion. Although at some age these fish undergo a considerable ontogenetic diet shift, they are characterised as omnivorous benthic consumers with molluscs constituting a substantial part of their diet (Kublickas 1959).

Rutilus rutilus is generally known to change from a zooplanktivore into a benthic omnivore, which later becomes particularly molluscivorous (Hellawell 1972, Szczyglińska 1987, Specziár et al. 1997). In temperate lakes, large $R$. rutilus is also known to switch to molluscs, especially dreissenids (Kublickas 1959, Naddafi et al. 2010). In Lake Dusia, abundance and biomass of D. polymorpha halved after $P$. antipodarum invasion (Rakauskas et al. 2018); on the other hand, R. rutilus consumed some $P$. antipodarum. Therefore, the decreased growth of larger $R$. rutilus, could be mostly explained by the reduction of the proportion of suitable prey and high accessibility of low-value prey subsequent to the domination of $P$. antipodarum in the macroinvertebrate assemblage.

Meanwhile, juvenile $P$. fluviatilis is a zooplankton feeder, which shifts to medium-sized macroinvertebrates during the second-third year (Hjelm et al. 2000, Rakauskas et al. 2010). When P. fluviatilis is large enough, its diet mainly consists of fish (Hjelm et al. 2000, Svanbäck and Eklöv 2002). Therefore, the slower growth of $3+-6+$ age $P$. fluviatilis individuals during the post-invasion period could be also explained by the changes in the taxonomic structure of the macroinvertebrate assemblage after $P$. antipodarum invasion.

Results of this study also showed a marked decrease in the total CPUE of littoral fish after P. antipodarum invasion. However, species-specific comparisons did not reveal any significant differences except for a significant decrease of $G$. cernua during the post-invasion period. Gymnocephalus cernua was indicated as a very specific benthivorous predator consuming considerable amounts of molluscs, which constituted a significant part of its diet in Lake Dusia, especially in autumn (Pilinkovskij et al. 2014). This would suggest that $G$. cernua could benefit from a severe invasion of $P$. antipodarum. However, previous studies revealed low consumption of P. antipodarum by G. cernua in Lake Dusia and other Lithuanian lakes (Rakauskas et al. 2016). Thus, reduction in CPUE of $G$. cernua could instead be explained by changes in the structure of macroinvertebrate assemblage, i.e. decrease in the proportion of more desirable and nutritious macroinvertebrates, such as crustaceans, consequent to $P$. antipodarum domination.

Concluding remarks. The high abundance of $P$. antipodarum increased the total biomass of littoral macroinvertebrates probably due to the increased consumption of basal food sources (Rakauskas et al. 2018). However, it also changed the structure of fish food basis in Lake Dusia. Our results showed that benthivorous fish consumed negligible amounts of over-dominant P. antipodarum even after several years since the invasion, thus the channelling of energy stored in primary production towards certain fish may have been reduced. Consequently, the invasion may have negatively affected the growth of at least several fish species and reduced their production rates. Through such proliferating effects, $P$. antipodarum may have thus decreased the total littoral fish production in the lake. In extrapolation of our results, P. antipodarum invasion could threaten fisheries of temperate lakes. Therefore, the expansion of $P$. antipodarum across European waters has serious international implications that require awareness, cooperation, and support from concerned citizens and governments.

\section{ACKNOWLEDGEMENTS}

Dr Audrius Steponėnas and Evelina Merkytė are greatly appreciated for their assistance in the field.

\section{REFERENCES}

Alonso A., Castro-Díez P. 2008. What explains the invading success of the aquatic mud snail Potamopyrgus 
antipodarum (Hydrobiidae, Mollusca)? Hydrobiologia 614 (1): 107-116. DOI: 10.1007/s10750-008-9529-3

Anonymous 2016. İsakymas Nr. D1-701 dèl Lietuvos Respublikos aplinkos ministro $2005 \mathrm{~m}$. gegužès $30 \mathrm{~d}$. ịsakymo Nr. D1-267 „Dėl verslinės žvejybos Lietuvos žuvininkystès vidaus vandens telkiniuose taisyklių patvirtinimo" pakeitimo. [Order no. D-710 of the Minister of Environment of the Republic of Lithuania in 2005 May 30 order No. D-267 'On the Approval of Rules for Commercial Fishing in Lithuanian Fisheries in Inland Water Bodies".] Lietuvos Respublikos aplinkos ministerija, Nr. 25788, Vilnius, Lithuania. [In Lithuanian.]

Arango C.P., Riley L.A., Tank J.L., Hall R.O. 2009. Herbivory by an invasive snail increases nitrogen fixation in a nitrogen-limited stream. Canadian Journal of Fisheries and Aquatic Sciences 66 (8): 1309-1317. DOI: 10.1139/F09-079

Arbaciauskas K. 2002. Ponto-Caspian amphipods and mysids in the inland waters of Lithuania: History of introduction, current distribution and relations with native malacostracans. Pp. 104-115. In: Leppäkoski E., Gollasch S., Olenin S. (eds.) Invasive aquatic species of Europe: Distribution, impacts and management. Springer, Dordrecht, the Netherlands. DOI: 10.1007/978-94-015-9956-6

Arbačiauskas K. 2005. The distribution and local dispersal of Ponto-Caspian Peracarida in Lithuanian fresh waters with notes on Pontogammarus robustoides population establishment, abundance and impact. Oceanological and Hydrobiological Studies 34 (Suppl. 1): 93-111.

Arbačiauskas K., Rakauskas V., Virbickas T. 2010. Initial and long-term consequences of attempts to improve fish-food resources in Lithuanian waters by introducing alien peracaridan species: A retrospective overview. Journal of Applied Ichthyology 26 (Suppl. 2): 28-37. DOI: 10.1111/j.1439-0426.2010.01492.x

Arbačiauskas K., Višinskienė G., Smilgevičienė S., Rakauskas V. 2011. Non-indigenous macroinvertebrate species in Lithuanian fresh waters, Part 1: Distributions, dispersal and future. Knowledge and Management of Aquatic Ecosystems 402 (12): e12. DOI: 10.1051/ $\mathrm{kmae} / 2011075$

Bennett D.M., Dudley T.L., Cooper S.D., Sweet S.S. 2015. Ecology of the invasive New Zealand mud snail, Potamopyrgus antipodarum (Hydrobiidae), in a Mediterranean-climate stream system. Hydrobiologia 746 (1): 375-399. DOI: 10.1007/s10750-014-2136-6

Bersine K., Brenneis V.E.F., Draheim R.C., Rub A.M.W., Zamon J.E., Litton R.K., Hinton S.A., Sytsma M.D., Cordell J.R., Chapman J.W. 2008. Distribution of the invasive New Zealand mudsnail (Potamopyrgus antipodarum) in the Columbia River Estuary and its first recorded occurrence in the diet of juvenile Chinook salmon (Oncorhynchus tshawytscha). Biological Invasions 10 (8): 1381-1388. DOI: 10.1007/s10530-007-9213-y

Brenneis V.E.F., Sih A., de Rivera C.E. 2011. Integration of an invasive consumer into an estuarine food web:
Direct and indirect effects of the New Zealand mud snail. Oecologia 167 (1): 169-179. DOI: 10.1007/ s00442-011-1962-8

Bubinas A. 1979. Pitanie ryb vodohroniliŝa Kaunasskoj GÈS akklimatizirovannymi $\mathrm{v}$ nem mièidami Kaspijskogo rliktogo kompleksa Mesomysis kowalewskyi Czern. (Paramysis lacustris). [Feeding of fish in the Kaunas Hydro-Electric Plant Water Reservoir by acclimatized in it Misidae of Mesomysis kowalewskyi Czern. (Paramysis lacustris) of the Caspian complex.] LTSR MA darbai C 4 (88): 89-95. [In Russian.]

Butkus R., Šidagytė E., Arbačiauskas K. 2012. Two morphotypes of the New Zealand mud snail Potamopyrgus antipodarum (J. E. Gray, 1843) (Mollusca: Hydrobiidae) invade Lithuanian lakes. Aquatic Invasions 7 (2): 211-218. DOI: 10.3391/ ai.2012.7.2.007

Butkus R., Šidagytė E., Rakauskas V., Arbačiauskas K. 2014. Distribution and current status of nonindigenous mollusc species in Lithuanian inland waters. Aquatic Invasions 9 (1): 95-103. DOI: 10.3391/ ai.2014.9.1.08

Carlsson N.O.L., Sarnelle O., Strayer D.L. 2009. Native predators and exotic prey-an acquired taste? Frontiers in Ecology and the Environment 7 (10): 525532. DOI: $10.1890 / 080093$

CarpenterS.R. 1996. Microcosmexperimentshavelimited relevance for community and ecosystem ecology. Ecology 77 (3): 677-680. DOI: 10.2307/2265490

Collado G.A. 2014. Out of New Zealand: Molecular identification of the highly invasive freshwater mollusc Potamopyrgus antipodarum (Gray, 1843) in South America. Zoological Studies 53 (1): e70. DOI: $10.1186 / \mathrm{s} 40555-014-0070-y$

Dybdahl M.F., Drown D.M. 2011. The absence of genotypic diversity in a successful parthenogenesis invader. Biological Invasions 13 (7): 1663-1672. DOI: $10.1007 / \mathrm{s} 10530-010-9923-4$

Filippenko D.P., Son M.O. 2008. The New Zealand mud snail Potamopyrgus antipodarum (Gray, 1843) is colonising the artificial lakes of Kaliningrad City, Russia (Baltic Sea Coast). Aquatic Invasions 3 (3): 345-347. DOI: 10.3391/ai.2008.3.3.11

Gasûnas I.I. 1959. Kormovoj zoomakrobentos zaliva Kuršû Mares. [The fodder macrozoobenthos of the Curonian Lagoon.] Pp. 191-291. In: Jankevičûs K. (ed.) Kuršû Mares. Itogi kompleksnogo issledovaniâ. [The Curonian Lagoon. Results of integrated research]. Akademiâ Nauk Litovskoj SSR, Institut Biologii, Gostipografiâ Pârgale, Vil'nius, Lithuania. [In Russian.]

Gasûnas I.I. 1970. Akklimatizaciâ cennyh bezpozvonočnyh - važnyj put' uveličenijâ biologičeskoj produktivnosti ozer. [Acclimatization of valuable invertebrates An important way to expand biological productivity of lakes]. Pp. 190-198. In: Manûkas Û.L. (ed.) Vsesoûznyj simpozjum po osnovnym problemam presnovodnyh ozër. [All-Union Symposium on the Principal Problems 
of Freshwater Lakes.]. Vol. 3. 25-29 May 1970, Vil'nius, Lithuania. [In Russian.]

Gasûnas I.I. 1972. Obogoŝenie kormovoj bazy ryb vodoemov Litvy akklimatizirovannymi rakoobraznymi Kaspijskogo kompleksa. [Enrichment of fodder basis of water bodies of Lithuania by acclimatized crustaceans-like organisms from the Caspian Sea complex.] Pp. 57-68. In: Manûkas Û.L., Virbickas Û. (eds.) Voprosy razvedeniâ ryb i rakoobraznyh $\mathrm{v}$ vodoemah Litvy. [On the breeding of fish and crustaceans-like organisms in the water bodies of Lithuania]. Mintis, Vil'nius, Lithuania. [In Russian.]

Gasûnas I.I. 1975. Perakarida iz ozera Dusâ (bassejn Baltijskogo morâ). [Peracarida from Lake Dusia (Baltic Sea basin).] Gidrobiologičeskij žurnal 11 (1): 46-50. [In Russian.]

Grigorovich I.A., Korniushhin A.V., Gray D.K., Duggan I.C., Colautti R.I., MacIsaac H.J. 2003. Lake Superior: An invasion coldspot? Hydrobiologia 499 (1-3): 191-210. DOI: 10.1023/A:1026335300403

Haag D., Matschonat G. 2001. Limitations of controlled experimental systems as models for natural systems: A conceptual assessment of experimental practices in biogeochemistry and soil science. Science of the Total Environment 277 (1-3): 199-216. DOI: 10.1016/ S0048-9697(00)00878-0

Hall R.O.jr., Tank J.L., Dybdahl M.F. 2003. Exotic snails dominate nitrogen and carbon cycling in a highly productive stream. Frontiers in Ecology and the Environment 1 (8): 408-411.

Hamada K., Tatara Y., Urabe M. 2013. Survey of mitochondrial DNA haplotypes of Potamopyrgus antipodarum (Caenogastropoda: Hydrobiidae) introduced into Japan. Limnology 14 (3): 223-228. DOI: $10.1007 / \mathrm{s} 10201-013-0405-0$

Hellmair M., Goldsmith G., Kinziger A.P. 2011. Preying on invasives: The exotic New Zealand mud snail in the diet of the endangered tidewater goby. Biological Invasions 13 (10): 2197-2201. DOI: 10.1007/s10530011-0054-3

Hellawell J.M. 1972. The growth, reproduction and food of the roach Rutilus rutilus (L.), of the River Lugg, Herefordshire. Journal of Fish Biology 4 (4): 469-486. DOI: $10.1111 /$ j.1095-8649.1972.tb05696.x

Hjelm J., Persson L., Christensen B. 2000. Growth, morphological variation and ontogenetic niche shifts in perch (Perca fluviatilis) in relation to resource availability. Oecologia 122 (2): 190-199. DOI: $10.1007 /$ PL00008846

Horppila J., Ruuhijärvi J., Rask M., Karppinen C., Nyberg K., Olin M. 2000. Seasonal changes in the diets and relative abundances of perch and roach in the littoral and pelagic zones of a large lake. Journal of Fish Biology 56 (1): 51-72. DOI: 10.1111/j.10958649.2000.tb02086.x

Jellyman D.J. 1989. Diet of two species of freshwater eel (Anguilla spp.) in Lake Pounui, New Zealand. New Zealand Journal of Marine and Freshwater Research 23 (1): 1-10. DOI: 10.1080/00288330.1989.9516334
Karatayev A.Y., Burlakova L.E., Padilla D.K. 1997. The effects of Dreissena polymorpha (Pallas) invasion on aquatic communities in eastern Europe. Journal of Shellfish Research 16 (1): 187-203.

Kerans B.L., Cada C.A., Zickovich J. 2010. Asymmetrical behavioural interactions between the New Zealand mud snail, Potamopyrgus antipodarum, and scraping, collector gathering and collector-filtering macroinvertebrates. Journal of Freshwater Ecology 25 (4): 657-666. DOI: 10.1080/02705060.2010.9664415

Kerans B. L., Dybdahl M.E., Gangloff M.M., Jannot L.E. 2005. Potamopyrgus antipodarum: Distribution, density, and effects on native macroinvertebrate assemblages in the Greater Yellowstone Ecosystem. The North American Benthological Society 24 (1): 123-138. DOI: 10.1899/0887-3593(2005)024<0123:PADDAE $>$ 2.0.CO;2

Kilkus K. 1998. Lietuvos vandenų geografija. [Geography of Lithuanian waters.] Apyaušris, Vilnius, Lithuania. [In Lithuanian.]

King R.B., Ray J.M., Stanford K.M. 2006. Gorging on gobies: Beneficial effects of alien prey on a threatened vertebrate. Canadian Journal of Zoology 84 (1): 108 115. DOI: $10.1139 /$ z05-182

Kublickas A. 1959. Pitanie bentosoâdnyh ryb Zaliva Kuršû mares. [Nourishment of bentic feeder fish in Curonian Lagoon.] P. 551. In: Ânkevičus K. (ed.) Kuršû mares. [Curonian Lagoon.] Pârgale, Vil'nûs. [In Russian.]

Kublickas A., Bubinas A. 1985. Rol' akklimatizirovannyh rakoobraznyh v pitanii ryb litoral'noj zony Kuršskogo zaliva. [The effect of acclimatized crustacean on the fish nutrition in the littoral zone of the Curonian Lagoon.] Acta Hydrobiologica Lituanica 5: 80-85. [In Russian.]

McCarter N.H. 1986. Food and energy in the diet of brown and rainbow trout from Lake Benmore, New Zealand. New Zealand Journal of Marine and Freshwater Research 20 (4): 551-559. DOI: $10.1080 / 00288330.1986 .9516175$

Moore J.W., Herbst D.B., Heady W.N., Carlson S.M. 2012. Stream community and ecosystem responses to the boom and bust of an invading snail. Biological Invasions 14 (11): 2435-2446. DOI: $10.1007 / \mathrm{s} 10530-012-0240-y$

Múrria C., Bonada N., Prat N. 2008. Effects of the invasive species Potamopyrgus antipodarum (Hydrobiidae, Mollusca) on community structure in a small Mediterranean stream. Fundamental and Applied Limnology 171 (2): 131-143. DOI: 10.1127/18639135/2008/0171-0131

Naddafi R., Pettersson K., Eklöv P. 2010. Predation on physical environment structure the density and population size structure of zebra mussels. The North American Benthological Society 29 (2): 444-453. DOI: 10.1899/09-071.1

Nalepa T.F. 1994. Decline of native unionid bivalves in Lake St. Clair after infestation by the zebra mussel, Dreissena polymorpha. Canadian Journal of 
Fisheries and Aquatic Sciences 51 (10): 2227-2233. DOI: 10.1139/F94-225

Nikolaev I.I. 1951. O novyh vselencah v faune i flore Severnogo morâ i Baltiki iz otdalennyh rajonov. [On new introductions in fauna and flora of the North and the Baltic Seas from distant areas.] Zoologičeskij Žurnal 30 (6): 556-561. [In Russian.]

Pilinkovskij A., Kesminas V., Bukelskis E., Čivas L. 2014. Ruffe (Gymnocephalus cernuus L.) growth and diet in Lake Dusia (southern Lithuania). Archives of Polish Fisheries 22 (2): 110-119. DOI: 10.2478/ aopf-2014-0010

Ponder W.F. 1988. Potamopyrgus antipodarum-a molluscan coloniser of Europe and Australia. Journal of Molluscan Studies 54 (3): 271-286. DOI: 10.1093/ mollus/54.3.271

Radea C., Louvrou I., Economou-Amilli A. 2008. First record of the New Zealand mud snail Potamopyrgus antipodarum J.E. Gray 1843 (Mollusca: Hydrobiidae) in Greece-Notes on its population structure and associated microalgae. Aquatic Invasions 3 (3): 341344. DOI: 10.3391/ai.2008.3.3.10

Rakauskas V., Butkus R., Merkytė E. 2016. Consumption of the invasive New Zealand mud snail (Potamopyrgus antipodarum) by benthivorous predators in temperate lakes: A case study from Lithuania. Hydrobiologia 775 (1): 213-230. DOI: 10.1007/s10750-016-2733-7

Rakauskas V., Pūtys Ž., Dainys J., Lesutienė J., Ložys L., Arbačiauskas K. 2013. Increasing population of the invader round goby, Neogobius melanostomus (Actinopterygii: Perciformes: Gobiidae), and its trophic role in the Curonian Lagoon, SE Baltic Sea. Acta Ichthyologica et Piscatoria 43 (2): 95-108. DOI: 10.3750/AIP2013.43.2.02

Rakauskas V., Smilgevičienė S., Arbačiauskas K. 2010. The impact of introduced Ponto-Caspian amphipods and mysids on perch (Perca fluviatilis) diet in Lithuanian lakes. Acta Zoologica Lituanica 20 (4): 189-197. DOI: 10.2478/v10043-010-0040-5

Rakauskas V., Šidagytė E., Butkus R., Garbaras A. 2018. Effect of the invasive New Zealand mud snail (Potamopyrgus antipodarum) on the littoral macroinvertebrate community in a temperate mesotrophic lake. Marine and Freshwater Research 69 (1): 155-166. DOI: 10.1071/MF17059

Riley L.A., Dybdahl M.F., Hall R.O.jr. 2008. Invasive species impact: Asymmetric interactions between invasive and endemic freshwater snails. Journal of the North American Benthological Society 27 (3): 509520. DOI: $10.1899 / 07-119.1$

Ryan P.A. 1982. Energy contents of some New Zealand freshwater animals. New Zealand Journal of Marine and Freshwater Research 16 (3-4): 283-287. DOI: $10.1080 / 00288330.1982 .9515971$

Sagar P.M., Glova G.J. 1995. Prey availability and diet of juvenile brown trout (Salmo trutta) in relation to riparian willows (Salix-spp.) in three New Zealand streams. New Zealand Journal of
Marine and Freshwater Research 29 (4): 527-537. DOI: $10.1080 / 00288330.1995 .9516685$

Sampaio E., Rodil I.F. 2014. Effects of the invasive clam Corbicula fluminea (Müller, 1774) on a representative macrobenthic community from two estuaries at different stages of invasion. Limnetica 33 (2): 249 262.

Schindler D.W. 1998. Whole-ecosystem experiments: Replication versus realism: The need for ecosystemscale experiments. Ecosystems 1 (4): 323-334. DOI: $10.1007 / \mathrm{s} 100219900$

Schlesch H., Krausp C. 1938. Zur Kenntniss der Land- und Süßwassermollusken Litauens. Archiv für Molluskenkunde 70: 73-125.

Schreiber E.S.G., Lake P.S., Quinn G.P. 2002. Facilitation of native stream fauna by an invading species? Experimental investigation of the interaction of the snail, Potamopyrgus antipodarum (Hydrobiidae) with native benthic fauna. Biological Invasions 4 (3): 317-325. DOI: 10.1023/A:1020925022843

Šivickis P.B. 1960. Baltijos jūros moliuskai Lietuvos TSR pajūryje. [Baltic Sea Molluscs at the coast of Lithuanian SSR.] LTSR MA darbai C (3): 125-132. [In Lithuanian.]

Son M.O. 2008. Rapid expansion of the New Zealand mud snail Potamopyrgus antipodarum (Gray, 1843) in the Azov-Black Sea Region. Aquatic Invasions 3 (3): 335-340. DOI: 10.3391/ai.2008.3.3.9

Specziár A., Tölg L., Bíró P. 1997. Feeding strategy and growth of cyprinids in the littoral zone of Lake Balaton. Journal of Fish Biology 51 (6): 1109-1124. DOI: 10.1111/ j.1095-8649.1997.tb01130.x

Svanbäck R., Eklöv P. 2002. Effects of habitat and food resources on morphology and ontogenetic growth trajectories in perch. Oecologia 131 (1): 61-70. DOI: $10.1007 / \mathrm{s} 00442-001-0861-9$

Szczyglińska A. 1987. Diet composition and daily feeding patterns of Rutilus rutilus (L.) in Włocławek Dam Reservoir in 1982-1984. Acta Ichthyologica et Piscatoria 17 (2): 55-68. DOI: 10.3750/ AIP1987.17.2.05

Thoresson G. 1993. Guidelines for Coastal Monitoring. Kustrapport 1. National Board of Fisheries, Institute of Coastal Research, Öregrund, Sweden.

Vinson M.R., Baker M.A. 2008. Poor growth of rainbow trout fed New Zealand mud snails Potamopyrgus antipodarum. North American Journal of Fisheries Management 28 (3): 701-709. DOI: 10.1577/M06039.1

Vinson M.R., Dinger E.C., Baker M.A. 2006. Flaming Gorge Tailwater aquatic biota monitoring programme, 1994-2005. Report to Utah Division of Wildlife Resources and U.S. Bureau of Reclamation, Salt Lake City, UT, USA.

Virbickas J. 1988. Struktura razvitie ihtiocenozov ozer Litvy. [Structure and development of ichthyocenoses in lakes of Lithuania.] Acta hydrobiologica Lituanica 8: 74-93. [In Russian.] 
Virbickas J., Kesminas V., Repečka R., Balkuvienė G. Virbickas T., Stakėnas S. 1996. Žuvų populiacinių parametrų būklè ir dinamika (1993-1995). [The state and dynamics of fish population parameters (1993-1995).] Pp 83-93. In: Stoškus L. (ed.) Aplinkos monitoringas 1993-1995. [Environmental monitoring 1993-1995.] Vilnius, Lithuania. [In Lithuanian.]

Virbickas T. 2013. Ichtiofaunos tyrimai bei ekologinès būklès pagal žuvų rodiklius ịvertinimas Lietuvos upėse ir ežeruose. [Fish fauna studies in Lithuanian rivers and lakes and their ecological status assessment based on the fish fauna metrics.] Gamtos tyrimų centro ataskaita, aplinkos apsaugos agentūra, Vilnius, Lithunania. [In Lithuanian.]

Virbickas T., Stakẻnas S. 2016. Composition of fish communities and fish-based method for assessment of ecological status of lakes in Lithuania. Fisheries Research 173 (1): 70-79. DOI: 10.1016/j. fishres.2015.08.015
Watzin M.C., Joppe-Mercure K., Rowder J., Lancaster B., Bronson L. 2008. Significant fish predation on zebra mussels Dreissena polymorpha in Lake Champlain, U.S.A. Journal of Fish Biology 73 (7): 1585-1599. DOI: 10.1111/j.1095-8649.2008.02033.x

Wetzel R.G. 2001. Benthic animals and fish communities. Pp. 665-730. In: Wetzel R.G. (ed.) Limnology. Lake and river ecosystems. 3rd edn. Academic Press, San Diego, CA, USA.

Winterbourn M. 1970. The New Zealand species of the genus Potamopyrgus (Gastropoda: Hydrobiidae). Malacologia 10 (2): 283-321.

Zettler M.L., Daunys D. 2007. Long-term macrozoobenthos changes in a shallow boreal lagoon: Comparison of a recent biodiversity inventory with historical data. Limnologica-Ecology and Management of Inland Waters 37 (2): 170-185. DOI: 10.1016/j.limno.2006.12.004

Received: 18 June 2017 Accepted: 17 January 2018 Published electronically: 31 March 2018 
